Віддалені результати кріодеструкції щитовидної залози у щурів із моделлю дифузної гіперплазії

К.О. Побєлєнський, Є.І. Легач

Інститут проблем кріобіології і кріомедицини НАН України, м. Харків, Україна

\section{Long-Term Outcomes of Thyroid Cryoablation in Rats With Model of Diffuse Hyperplasia K.O. Pobelensky, E.I. Legach}

Institute for Problems of Cryobiology and Cryomedicine of the

National Academy of Sciences of Ukraine, Kharkiv, Ukraine

Thyroid gland (TG) cryoablation as one of the methods of minimally invasive intervention has several advantages compared to traditional methods, including the possibility of percutaneous approach under the control of endoscopic techniques, minimizing anesthesia and risk of bleeding, reducing the time of postoperative care, and a good cosmetic result. However, for the widespread introduction of the method into a clinical practice, it is necessary to answer the number of questions, including characterizing the features of the process of reparative regeneration of the residual thyroid tissue after cryoablation.

The aim of the work was to study the long-term outcomes of thyroid cryoablation in rats with a model of propylthiouracil-induced diffuse hyperplasia.

The experiments were performed in female SHR rats of 6 months' age. To obtain diffuse TG hyperplasia, the animals received $0.1 \%$ solution of propylthiouracil (PTU) in drinking water for 90 days. After this, the rats were divided into 2 groups. Rats of the $1^{\text {st }}$ group $(n=14)$ were subjected to a surgical access and double cryogenic action for $120 \mathrm{sec}$ in the left lobe of the TG. A copper cryoprobe cooled to $-196^{\circ} \mathrm{C}$ with a tip diameter of $1.5 \mathrm{~mm}$ and a volume of the cooled part of $21.99 \mathrm{~cm}^{3}$ was used. Rats of the $2^{\text {nd }}$ group $(n=12)$ underwent all the manipulations except cryoablation (shamoperated control). On the $30^{\text {th }}, 60^{\text {th }}$ and $120^{\text {th }}$ days, the animals were decapitated and blood was taken to measure TSH, free T3 and T4 by ELISA, and thyroid residue for the preparation of histological slides. Thyroid tissue regeneration parameters such as follicular epithelium height (FEH), the number of C-cells, interfollicular islets (IFI), and follicles of irregular shape (FIS) were examined. The statistical significance of the differences between the groups was evaluated using the non-parametric Mann-Whitney test, the differences were considered significant at $p<0.05$.

The significant increase in TSH levels (by 6 times) and the tendency towards a decrease in the levels of free T4 (by 1.5 times) were found in rats of the $1^{\text {st }}$ group 30 days after surgery. On the $60^{\text {th }}$ and $120^{\text {th }}$ days, no differences in hormone levels were observed compared with the sham-operated control. Analysis of histological sections demonstrated a significant increase in the number of IFI (by 2.6 times) and FIS (by 2.7 times) in animals of the $1^{\text {st }}$ group at all the studied terms. The number of C-cells and FEH increased by 1.5 and 1.1 times, respectively.

Thus, in the thyroid tissue after double cryogenic action for $120 \mathrm{sec}$, the histomorphological signs of reparative regeneration are observed, which actively proceed throughout the entire studied period.
Probl Cryobiol Cryomed 2020; 30(3):285

https://doi.org/10.15407/cryo30.03a.285

\section{Успішне кріоконсервування фібробластів за рахунок зниження концентрації ДМСО та додавання нанокристалічного діоксиду церію \\ О.В. Поліванова, О.Н. Боброва, О.С. Сидоренко, \\ О.В. Фалько, В.В. Чижевський \\ Інститут проблем кріобіології і кріомедицини НАН України, м. Харків, Україна}

\section{Successful Cryopreservation of Fibroblasts by DMSO Concentration Decreasing and Nanocrystalline Cerium Dioxide Adding O.V. Polivanova, O.M. Bobrova, O.S. Sidorenko, O.V. Falko, V.V. Chyzhevskyi \\ Institute for Problems of Cryobiology and Cryomedicine of the National Academy of Sciences of Ukraine, Kharkiv, Ukraine}

Usually during cryopreservation of fibroblasts the cryoprotectant dimethyl sulfoxide (DMSO) is used. But it is known that it can be toxic, therefore the search for additional measures to eliminate this negative effect remains relevant. A way to solve this issue may be to reduce DMSO concentration by applying nanocrystalline cerium dioxide ( $\mathrm{CeO}_{2}$ NPs), which presumably can affect on ice crystal formation. Such properties of $\mathrm{CeO}_{2} \mathrm{NPs}_{\text {say }}$ be in demand in cryobiological practice. In the previous studies, an attempt was made to reduce the concentration of DMSO to 1 and $5 \%$ during cryopreservation of L929 mouse fibroblasts.

To test an assumption either $\mathrm{CeO}_{2} \mathrm{NPs}$, as a component of cryoprotective medium based on DMSO, affects ice crystal formation, the solutions of DMSO and $\mathrm{CeO}_{2}$ NPs using differential scanning calorimetry were investigated. Samples were frozen in liquid nitrogen; the average cooling rate was $200^{\circ} \mathrm{C} / \mathrm{min}$. Thermograms were recorded at the heating stage of frozen solutions. To identify the cryoprotective properties of $\mathrm{CeO}_{2}$ NPs, after L929 mouse fibroblasts cryopreservation in $1 \%$ and $5 \%$ DMSO with $1 \mathrm{~g} / \mathrm{l} \mathrm{CeO}$ NPs, the viability, and the number of apoptotic cells were determined using flow cytometry (BD FACS Calibur, USA). A vital DNA dye 7AAD and a highly specific phosphatidylserine protein Annexin V were used, respectively. The cells cryopreserved with $1 \%$ DMSO only made the control group.

The study showed that the addition of $\mathrm{CeO}_{2} \mathrm{NPs}$ to $1 \%$ DMSO solution led to the appearance of heat absorption in the thermogram, which corresponded to devitrification. It indicates that nanoparticles affect water structure in the solution, increasing its tendency to supercooling and transition to vitreous state when reaching $-105^{\circ} \mathrm{C}$. The crystallization temperature of the eutectic formulations with the addition of $\mathrm{CeO}_{2} \mathrm{NPs}$ increases by $5.5^{\circ} \mathrm{C}$. However, $\mathrm{CeO}_{2}$ NPs had no significant effect on the melting point of the eutectic compositions and ice.

In the fibroblast samples cryopreserved with $\mathrm{CeO}_{2} \mathrm{NPs}$ and $1 \% \mathrm{DMSO}$, the number of $7 \mathrm{AAD}^{+}$and Annexin $\mathrm{V}^{2}$ cells was $(49.90 \pm 4.96) \%$ and $(48.44 \pm 2.19) \%$, respectively. Samples with $\mathrm{CeO}_{2}$ NPs and 5\% DMSO contained $26.99 \pm$ $\pm 4.717 \mathrm{AAD}^{+}, 30.97 \pm 4.76$ Annexin $\mathrm{V}^{+}$cells. In the control samples, the number of $7 \mathrm{AAD}^{+}$cells was $(64.29 \pm 5.22) \%$ and the number of Annexin $\mathrm{V}^{+}$cells was $(77.67 \pm 2.34) \%$.

Thus, the study showed that the addition of cerium nanoparticles allowed to reduce DMSO concentration for L929 mouse fibroblasts cryopreservation, because it increased the crystallization temperature of eutectic compositions as well as cell viability, and reduced the number of apoptotic cells. 